\title{
Toward energy efficiency measures for design of the IDB-funded integrated classroom building in Universitas Negeri Malang
}

\author{
Apif M. Hajji1 ${ }^{1,2 *}$ \\ ${ }^{1}$ Department of Civil Engineering, Universitas Negeri Malang, Malang, Indonesia \\ ${ }^{2}$ Program In-Charge and Technical Team Coordinator, the Office of Project Implementation Unit \\ (PIU) for the IDB-funded 4in1 Project at Universitas Negeri Malang, Malang, Indonesia
}

\begin{abstract}
Under the support from the Islamic Development Bank (IDB), Universitas Negeri Malang (UM) is going to build two-identical nine storey integrated classroom buildings. The buildings were designed to have green building certificate by proposing and fulfilling the requirements from the Green Building Council Indonesia (GBCI) rating system. For design recognition (DR) phase, the system requires efforts and measures in energy efficiency. The paper analyses all design aspects and criteria included in the working drawings, technical specifications, and bill of quantities as provided in the buildings detailed-engineering-design (DED). The analysis covers the calculation of overall thermal transfer value (OTTV), artificial lighting, vertical transportation, and air conditioning system. By using energy modelling software, the OTTV for Building A and Building B, with $19,445.13 \mathrm{~m}^{2}$ of total floor area using VRF-AC system, are $31.78 \mathrm{~W} / \mathrm{m}^{2}$ and $33.48 \mathrm{~W} / \mathrm{m}^{2}$ respectively. The proposed annual energy use is 3510.90 MWh with the index of energy consumption is $180.55 \mathrm{kWh} / \mathrm{m}^{2}$ per-year. The results showed that by achieving $32.58 \%$ of energy efficiency, the DR of UM's two classroom buildings is affordable to attain 11 points in the rating system.
\end{abstract}

\section{Introduction}

As part of the establishment of Center of Excellence (CoE) for Learning Innovation, Universitas Negeri Malang (UM) has received a loan grant from the Islamic Development Bank (IDB). By this grant, UM has to manage all resources to conduct both hard programs and soft programs in a campaign to the $\mathrm{CoE}$, which has to be supported by high-quality learning infrastructure, including new two 9-stories integrated classroom buildings. As the required learning facility to seed the atmosphere of innovation, the buildings not only have to be equipped with the innovative-stimulus type of design but also have to reflect its responsibility for the better quality of campus environment.

The buildings will be proposed to obtain a green-ship certificate for its design recognition (DR). The targeted green-ship for is released by Green Building Council

\footnotetext{
*Corresponding author: apif.miptahul.ft@um.ac.id
} 
Indonesia (GBCI) and requires some assessment of the building's technical specification for gaining points in the DR rating system. This study tried to analyze the technical aspects of energy efficiency approaches and measures as part of the DR rating system parameters. The analysis covers the calculation of overall thermal transfer value (OTTV), artificial lighting, vertical transportation, and air conditioning system. The design of two integrated classroom buildings is shown in Fig. 1.

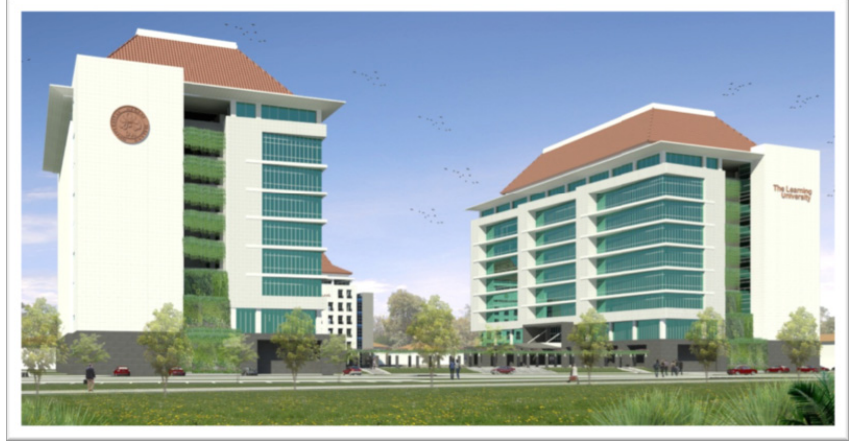

Fig. 1. The design of two integrated classroom buildings in UM.

\section{Related studies}

Many studies approach energy efficiency measures in building constructions. Some studies have conducted in adjusting energy data for analyzing energy use in buildings and its relationship with LEED credits' Optimize Energy Performance scores in building energy efficiency [1]. In term of green strategy, the integration of technology (use of building information management tools, sustainable construction materials), organization (formulating, applying, monitoring, and evaluating green action plans), occupants' behaviors (education, encouragements, energy efficiency guide) will significantly reduce energy use of green building in many countries [2]. As for the housing industry (real estate developers), some studies have proven that the industry is not completely employed with the energy-efficiency approaches. That developers represent an unreliable level of ability to provide energy-efficient housings [3].

The use of consultant for reducing energy use in commercial and educational buildings also plays a significant role. Its intervention to green building concept is delivered by the use of some green rating tools and instruments [4, 5, 6, 7]. In term of design, the use of passive solar heat gain techniques and components, building orientation and position on site, glazing techniques, play the very important part in defining building's green methods. It has also been proven that the design can contribute to the reduction of energy use $[8,9]$. The data of energy profiles can also be used to investigate some alternatives for reducing the energy use in buildings. Building Energy Management System (BEMS) can give the building users and operating management to develop some retrofitting approaches in measuring energy use in buildings $[10,11]$. These BEMS can be collectively combined with current rooms HVAC technologies and other efficiency methods, such as building insulation or even with the measures of greenhouse gas (GHG) emissions from building construction. Furthermore, it is important not only to promote the design of energy-efficient buildings but also to focus on the exemplified energy of a building concept. It leads to the consideration of the energy prerequisite for the construction and operation of the buildings and, therefore, to maintain the building's full life cycle. This is a more challenging 
approach not only for most building designers and planners but also for all stakeholders in the construction industry [12].

In addition to building design aspect, methods in modeling-optimizing net-zero energy are also important. Building performance optimization (BPO), which is complemented with building performance simulation (BPS) is a most likely encouraging answer for assessing various design alternatives and gaining the optimum solutions for a given objective. Many studies also investigate the statistical approaches for building energy analysis. The use of support vector regression (SVR), artificial neural network (ANN), and recursive deterministic perceptron (RDP) neural network is among intelligent models in predicting energy consumption, particularly in implementing fault detection and diagnosis (FDD) of building energy consumption [13].

\section{Method}

The energy efficiency and conservation (EEC) methods in GBCI's green-ship focuses not only on technology use transformation but also on the facility installations which can support the monitoring and recording of electricity consumption. The energy consumption in the design of two integrated classroom buildings is calculated by using energy modeling software Integrated Environmental Solutions (IES). This software calculates the baseline and designed energy consumption based on DED documents and building's technical specifications. The different results from baseline and design are defined as efficiency. For each $2.5 \%$ of efficiency, the DR will have 1 point of greens. The items calculated for energy efficiency measures and its targeted points are shown in Table 1.

Table 1. Components in energy efficiency measures in GBCI's greenship.

\begin{tabular}{|c|c|c|}
\hline \multirow{2}{*}{ OTTV } & $\begin{array}{l}\text { OTT values are based on SNI 03-6389-2011 for building } \\
\text { envelope energy conservation }\end{array}$ & \multirow{2}{*}{$\begin{array}{c}5 \\
\text { points }\end{array}$} \\
\hline & $\begin{array}{l}\text { Reduction of energy up to } 2.5 \mathrm{~W} / \mathrm{m}^{2} \text { will have } 1 \text { to } 2 \text { greenship } \\
\text { point }\end{array}$ & \\
\hline \multirow{4}{*}{ Artificial lighting } & $\begin{array}{l}\text { Using luminaire with lower lux by } 15 \% \text { compared to SNI } 03- \\
6197-2011 \text { for energy conservation in lighting system }\end{array}$ & \multirow{4}{*}{$\begin{array}{c}2 \\
\text { points }\end{array}$} \\
\hline & Using $100 \%$ high-frequency ballast for working spaces & \\
\hline & Lighting zones for all working spaces with motion sensors & \\
\hline & Installing reachable switching panels near entrance doors & \\
\hline \multirow{2}{*}{$\begin{array}{l}\text { Vertical } \\
\text { transportation }\end{array}$} & $\begin{array}{l}\text { Using elevators with traffic management system (assessed by } \\
\text { traffic analysis or regenerative drive system) }\end{array}$ & \multirow{2}{*}{$\begin{array}{c}1 \\
\text { points }\end{array}$} \\
\hline & $\begin{array}{l}\text { Using energy efficient features or, for elevators, or 'sleep mode' } \\
\text { for escalators }\end{array}$ & \\
\hline $\begin{array}{l}\text { Air conditioning } \\
\text { system }\end{array}$ & $\begin{array}{l}\text { Using AC system with COP } 10 \% \text { bigger than SNI 03-6390-2011 } \\
\text { for energy conservation at building air conditioning system }\end{array}$ & $\begin{array}{c}2 \\
\text { points }\end{array}$ \\
\hline
\end{tabular}

The variables of DED documents needed to be analyzed are similar to those in the GBCI's energy efficiency calculation worksheet. As for baseline calculation, the basis used in the analysis is gross floor area. The variables are:

1. Building's basic data (location, block plan drawings, and the function of the building). 
2. Building's total area (gross floor area, air conditioning targeted area, non-air conditioning area, and area for artificial lighting).

3. The height of each floor.

4. Zoning at each floor (codes, zone plan drawings, and scale).

5. Function-based activity data (room's occupancy density, average metabolism of designed activities, typical user's clothes, user's activity schedule, and office equipment load).

6. Lighting intensity.

7. Building envelope (material layering for opaque and transparent walls, the thickness of the walls, building elements-based heat transmission values).

8. Fan coil unit calculation (auxiliary energy, coefficient of performance, AC schedule, air supply temperature, air supply humidity ratio, cooling system distribution, designed air distribution types, and environmental control system).

\section{Results and discussion}

From DED documents, it is observed that three main components to be calculated by using IES are air conditioning system (fan coil unit, pump for AC water cooled, indoor units, chiller, air handling unit, and cooling tower), lightings (indoor luminaires and 1-phase power sockets), and other electric equipment (water pumps, lift, escalators, mechanical ventilation, and non-AC 3-phase power sockets).

The baseline for total energy consumption per year of UM's two new integrated classroom buildings is 5,207.76 MWh, with energy consumption index is $267.81 \mathrm{kWh} / \mathrm{m}$ year. This energy consumption includes $17.41 \%$ for electric equipment, $32.27 \%$ for lightings, and $50.32 \%$ for air conditioning system. This baseline calculation, which then will be compared to four different approaches of design, is based on $35 \mathrm{~W} / \mathrm{m}^{2}$ of OTTV at $19,445 \mathrm{~m}^{2}$ air-conditioned area, with $15 \mathrm{~W} / \mathrm{m}^{2}$ artificial lighting, and by using COP 3.7VRF type of air conditioning system. The comparison of four different designs for energy efficiency is displayed in Table 2.

Table 2. Energy efficiency calculation results.

\begin{tabular}{|c|c|c|c|c|}
\hline Components & Design 1 & Design 2 & Design 3 & Design 4 \\
\hline OTTV Bldg $1\left(\mathrm{~W} / \mathrm{m}^{2}\right)^{* *}$ & \multicolumn{4}{|c|}{31.78} \\
\hline OTTV Bldg $2\left(\mathrm{~W} / \mathrm{m}^{2}\right)^{* *}$ & \multicolumn{4}{|c|}{33.48} \\
\hline Air conditioned area $\left(\mathrm{m}^{2}\right)^{* *}$ & \multicolumn{4}{|c|}{$19,445.13$} \\
\hline Type of $\mathrm{AC}^{* *}$ & \multicolumn{4}{|c|}{ VRF - COP 4.1} \\
\hline $\begin{array}{l}\text { Artificial Lighting (on average; } \\
\qquad \mathrm{W} / \mathrm{m}^{2} \text { ) }\end{array}$ & 6 & 4 & 4 & $\begin{array}{l}4 \text { and Lux } \\
\text { Sensors }\end{array}$ \\
\hline Additional System Design & - & - & $\begin{array}{c}\text { AC set point } \\
25^{\circ} \mathrm{C} \text { and } \\
\text { Humidity } \\
60 \%\end{array}$ & $\begin{array}{c}\text { AC set point } \\
25^{\circ} \mathrm{C} \text { and } \\
\text { Humidity } \\
60 \% \\
\end{array}$ \\
\hline Energy Use per-year (MWh) & 4337.53 & 3807.66 & 3622.18 & 3510.90 \\
\hline $\begin{array}{c}\text { Energy Consumption Index } \\
\left(\mathrm{kWh} / \mathrm{m}^{2} \text {.year }\right)\end{array}$ & 223.06 & 195.82 & 186.28 & 180.55 \\
\hline Efficiency (from baseline) & $16.71 \%$ & $26.88 \%$ & $30.45 \%$ & $32.58 \%$ \\
\hline Targeted Greenship Points & 4 & 8 & 10 & 11 \\
\hline
\end{tabular}

**based on design, technical specification and working drawings in DED documents. 
Table 2 shows that by using design and technical specification as included in DED documents, there are possibilities in achieving efficiency in energy consumption. Because the largest share of building energy is used for air conditioning system, some additional system or alternative approaches are applied to it. Some given components are derived from the actual design of the buildings, such as the use materials for façade, type, and area of windows, room plans and shapes, the height of the floors, building orientation, and type of AC system. Those components are analyzed and simulated by using IES software (Fig. 2). Alternative designs for energy efficiency can be calculated from some variables, such as the lighting system or additional features in the AC system.

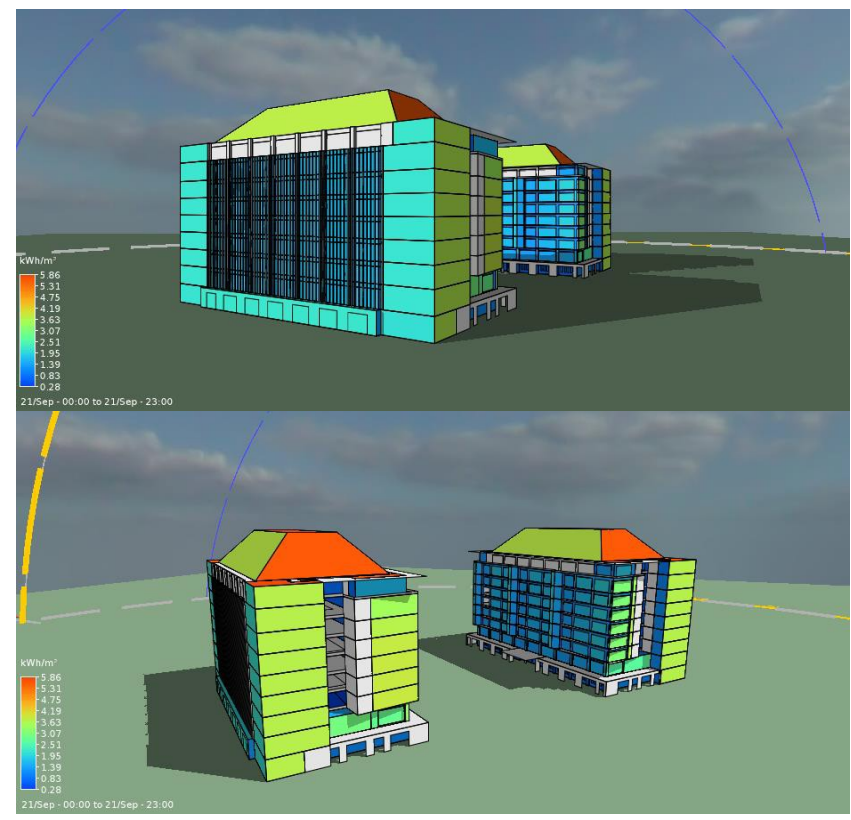

Fig. 2. Energy simulation results from the IES software calculation.

By setting up the lighting system energy on average of $6 \mathrm{~W} / \mathrm{m}^{2}$, the buildings will consume $4337.53 \mathrm{MWh}$ per year or gaining $16.71 \%$ of efficiency (Design 1). When the use of lighting system energy is reduced to $4 \mathrm{~W} / \mathrm{m}^{2}$, the annual energy consumption index will also drop to $195.82 \mathrm{kWh} / \mathrm{m}^{2}$ per year, or equals to $26.88 \%$ of efficiency (Design 2). This reduction of lighting system energy may have 8 points of green-ship. To gain more efficiency, some efforts to modify some components cloud be applied. In Design 3, after reducing the lighting system to $4 \mathrm{~W} / \mathrm{m}^{2}$, the temperature of the AC system design has been set on $25^{\circ} \mathrm{C}$ on default with $60 \%$ humidity. According to IES simulation results, this approach can reduce the annual energy consumption to $3622.18 \mathrm{MWh}$ or equals to $30.45 \%$ efficiency. By adding this setting for the AC system, the possible green-ship point obtained is 10 . To increase the possible green-ship target by 1 point, an additional feature is put on the lighting system. Lux sensors are installed to make sure that all luminaires will not exceed its required intensity (lumen). Installed after reducing the average lighting system energy to $4 \mathrm{~W} / \mathrm{m}^{2}$, and using higher temperature and humidity sets for $\mathrm{AC}$, this alternative possibly reduces the annual energy consumption to $3510.90 \mathrm{MWh}$ or equals to $32.58 \%$ of efficiency. By this Design 4, the green-ship point of energy efficiency measures for UM's two integrated classroom buildings is targeted on 11 points. 


\section{Conclusions}

Energy efficiency as part of green-ship for Design Recognition (DR) of UM's two integrated classroom buildings can be achieved by applying some technical modification to its design components. Adding some features, new systems, or changing in building materials or other controlled technical specification can significantly reduce the use of energy. The targeted green-ship points in DR phase has to be proven until the existing design is constructed. It is proven that by adding small changes in existing design, such as reducing the lighting energy or small sensors, the overall energy use is significantly reduced.

\section{References}

1. J. Kim, J. Hyun, W.K. Chong, S. Ariaratnam. J. of Eng. Design and Tech. 15, 3 (2017)

2. C.C. Ohueri, W.I. Enegbuma, R. Kenley. Built Env. Proj. and Asset Man. 8, 2 (2018)

3. N. Callaghan, J. Sommerville, N. Craig. Int. J. of Housing Markets and Analysis 7, 3 (2014)

4. N. Ofori-Boadu, M.A. Shofoluwe, D. Owusu-Manu, G.D. Holt, D. Edwards. Built Env. Project and Asset Man. 5, 4 (2015)

5. B. Glumac, M.A. Oosterbaan, W.F. Schaefer, K. Sulla. J. of Corporate Real Estate 17, 2 (2015)

6. N. Soares, L.D. Pereira, J. Ferreira, P. Conceição, P.P. da Silva. Int. J. of Sust. in Higher Edu. 16, 5 (2015)

7. J. Morrissey, N. Dunphy, R. MacSweeney. J. of Property Investment \& Finance 32, 4 (2014)

8. R. Fallahtafti, M. Mahdavinejad. Int. J. of Energy Sector Man. 9, 4 (2015)

9. C.M. Clevenger, J.R. Haymaker. Smart and Sustainable Built Env. 1, 3 (2012)

10. N. Maistry, H. Annegarn. Int. J. of Sustainability in Higher Edu. 17, 2 (2016)

11. S. Beucker, J.D. Bergesen, T. Gibon. J. of Industrial Ecology 20 (2016)

12. M. Balouktsi, T. Lützkendorf. Energy Techn. 4 (2016)

13. C. Duarte, P. Raftery, S. Schiavon. Energy Tech. 84, 6 (2018) 